\title{
Embrace of Christianity and reaction to conquest: Transformative role of South African independent churches
}

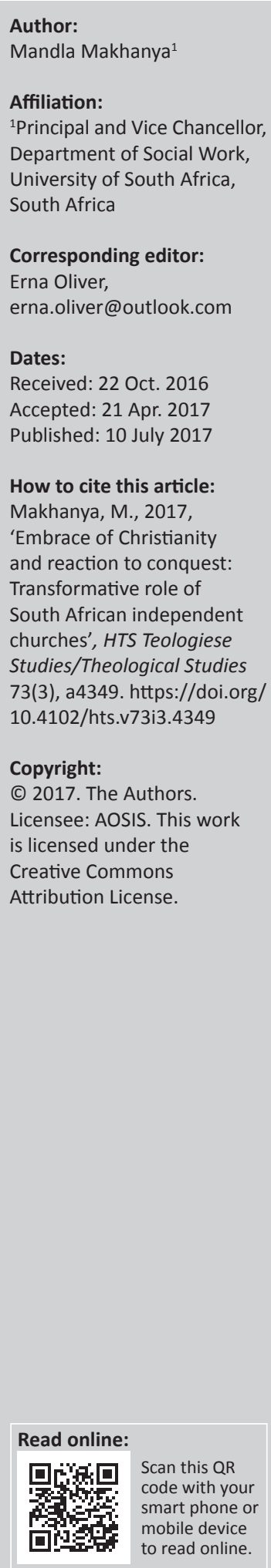

Reformation is one of the most phenomenal movements in human history. It had a profound, epoch-defining and transformative impact on Christianity and on the whole world. What was initiated as an effort to improve and change aspects of the then dominant Catholic system evolved into a new faith known as the Protestant Movement inspired and instigated by a German monk, Martin Luther. What began in 16th-century Europe as a localised reaction to Catholicism would divide the Christian faith into two major groups throughout the world. As scholars throughout the world reflect and commemorate 500 years since Reformation, they will certainly come to a common conclusion that this was one of the most important transformative events in modern human history, and in Christian church history in particular, no matter what their perspectives or revisions might be.

As scholars focus on that seminal moment of radical changes brought by Reformation and Counter-Reformation in Europe, they may easily overlook and gloss over some important developments that took place in various colonies where missionaries introduced Christianity often parallel or linked to colonial conquest. Most of the mainstream literatures tend to focus on the change agency of missionaries for converting indigenous people groups to Christianity, and the modernising influence of the colonial project, without much attention being given to the indigenous communities and individuals who had to contend with these profound changes on their way of life. A considerable amount of literature often emphasise warrior traditions and the military role of indigenous Africans as they resisted colonial conquest and hardly ever acknowledge the sophisticated intellectual role of African agency in the early encounters with the Europeans. In the historiography of African struggles against colonialism and African nationalism, an uncritical adoption of a narrative that simply attributes these to the introduction of missionary schools that enlightened the modern African elite is often embraced without giving credit to African agency. We need to give a narrative dignity to African Christian converts as well as amplify the specific agency role of African independent churches (AICs) who sought to reform what was largely European and adapt Christianity to their African context.

It should be stated that the phenomenon of AICs is not confined to South Africa as it is to be found in most colonial and post-colonial countries that converted to Christianity. There are few notable writings that describe and analyse this phenomenon. This category of churches is known as African indigenous churches or African initiated churches. They are further divided into two major types, called Ethiopianism and Zionist churches. Ethiopian movement churches mainly consist of African-led churches that broke away from the established Protestant and Catholic churches but continue to maintain much of the doctrine and liturgy. Contrary to this, Zionist African churches tend to part significantly from the established doctrine and liturgy and give prominence to African spirituality and customary practices and rituals. These churches and their leaders planted the early seeds of modern African national consciousness which subsequently led to nationalist struggles for liberation that reached their maturity in the post-Second World War period. The establishment of AICs was largely a reaction to colonial conquest and European missionary domination as well as rigid application of the Christian doctrine and liturgy that sought to destroy the traditional African way of life and world view. Many Africans embraced Christianity and converted but reacted against colonial dispossession and conquest as well as missionary domination by establishing their own independent churches with a strong African heritage and cultural flavour to it. It can therefore be claimed that the establishment of the AICs brought about reformation and transformation to the very Christian doctrine and practices associated with it, while also instigating a new form of self-consciousness among the indigenous African communities. The pioneers of these churches easily fit the profile of change agents who defined changes in their societies using an adapted Christian platform. This demonstrably 
challenges the notion that most Africans were passive in their conversion to Christianity.

South Africa is one of the most important areas where the impact and profile of AICs are well pronounced as indicated by the following facts. It is estimated that about $80 \%$ of South Africans are Christians and about $40 \%$ belong to the churches classified as AICs. According to Oosthuizen (2000), these churches had about 11 million adherents by the year 2000, and surely that number has increased since then. The most prominent of these is the Lekganyane's Zionist Christian Church, Shembe's Church of Nazareth, Modise International Pentecost Holiness Church and the various Ethiopian Movement churches. Many of these vibrant churches have been in existence for almost 100 years alongside and sometimes in competition with the mainstream Christian churches; therefore, they are a religious force to reckon with. The significance of the AICs in South Africa is clearly demonstrated by the aforementioned figures, which suggest that this group of churches is in the mainstream of Christian faith, particularly among black Africans. During the late 19th and early 20th centuries, some among the first cohort of black clergy consciously took a position to persuade their followers to embrace Christianity but adapt it to the African way of life and also to challenge European domination of the church establishment which was discriminatory of nature. It was also this pioneering black clergy that was instrumental in the formulation of African national consciousness often using the biblical principles as a justification in their quest for justice and equality.

Serious efforts to convert indigenous Africans in the new colonies of South Africa commenced in the latter part of the 18th century mainly among the Khoisan in the Cape, and spread to Xhosa people in the frontier region of the Eastern Cape during the 19th century. As more Africans were being brought under the colonial administration, colonies and mission stations established this spread to the rest of South Africa. During the establishment phase mission stations often built schools, hospitals and other agricultural or development projects as part of the modernisation programme. This wave of modernisation also introduced formal education in the mission schools. It was mainly in these institutions that the first generation of Africans with formal western education was produced, and among them emerged educated converts who would assume leadership roles in their respective churches. A privileged few would even be taken abroad for training as priests, like Reverend Tiyo Soga of the Presbyterian Church.

Some of the churches that became the mainstream establishment among the indigenous Africans by the 19th century include the Presbyterians, Wesleyan Methodists, Roman Catholics, Anglicans and Moravians. Just as was the case with the Christian Reformation Movement that took place in Europe, the establishment of AICs was as political as it was religious in character. What were the factors behind the establishment of the breakaway or African initiated churches?
While the reasons and circumstances varied from one region to the other, and from one denomination to the other, there are, however, some threads that seem to be common among them. These include, but are not limited to:

1. Reaction to European colonial conquest and dispossession of Africans. Christian conversion was closely associated with this colonial and imperial project without clear distinction of the two.

2. Reaction to European domination and monopoly of leadership positions in churches with African congregants. The European domination of the church had hierarchy with little or no opportunities of African social mobility within the system.

3. Church doctrines and liturgy that seek to obliterate the African way of life and world view without any flexible interpretation of the Bible to accommodate cultural and heritage diversity.

4. Needs for Africans to establish churches that embrace their traditional, cultural and customary practices.

5. Establishment of links between African Americans and other Africans in the diaspora and those in the African continent resulting in the sharing of experiences of struggles against slavery, racial segregation and oppression in all its variants.

6. A general African reaction to the calamities and great hardships emanating from their military conquest, dispossession of land and livestock, socio-economic depression and the search for messianic leadership and redemptive movement.

Most of the African societies were organised as chiefdoms or kingdoms under traditional leaders who also played a crucial role in the introduction or accommodation of Christianity among their subjects. This, to most of them, was a doubleedged sword that brought strategic political and diplomatic benefits that captured not only the essence of this dilemma, at a secular level, but also persuaded subjects to drift away from traditional customary practices. The following articulation by Cope (1979) apprehends the essence of this dilemma:

It is true that the chiefs generally welcomed missionaries; but this was because of their usefulness in such secular spheres as diplomacy and technology. Their religious and moral teachings necessarily involved an attack on African customs, and so were perceived as subversive on the social order and of chiefly authority. This, together with the missionaries' association with the British colonial authority, made conversion appear an act of disloyalty. A convert was seen as casting off his own people and throwing his lot with the Whites. (p. 1)

From the above-listed reasons for the establishment of the AICs, it is quite clear that this was largely because of the coincidence, therefore association, of colonial conquest, and the introduction of Christianity. Harsh and rapid socioeconomic and political changes brought by the expansion of colonial rule and introduction of Christianity were bound to alienate many converted Africans and reinforce traditional resistance of what was seen as European encroachment. It is 
quite remarkable that these great changes did not lead to a whole-scale rejection of Christianity and the missionary movement, but instead led to a self-conscious adaptation to the African conditions. Even more important is how within a generation or two, African church leaders had managed to embrace and reconfigure the Christian world view and spiritual dimension in their context. Most of the breakaway Ethiopian church leaders had first highlighted sharp contradictions and an inconsistent application of Christian doctrine by fellow European congregants and clergy as shown in discriminatory practices as well as a general lack of active condemnation or challenge of colonial injustices.

A link between the South African-based breakaway churches with those of more established African American churches also gave an impetus and institutional linkage on a global scale, for example, the affiliation of fledgling Ethiopian Movement churches in South Africa with the African Methodist Episcopal Church. This did not only open doors for access to resources and a wider global audience, but also tapped into an established intellectual heritage of African Americans who had been grappling with efforts to highlight contradictions between their slave experience and Christianity or the whole notion of common humanity and justice articulated in the Scriptures but not actually practised in the society.

A careful examination of some of the writings and petitions of the anti-establishment challenge by those who would later form breakaway churches indicates a sophisticated interpretation of biblical meaning of equality of humanity and the notion of justice. More than three centuries earlier, a German monk, Martin Luther, sought to reform and improve the Roman Catholic Church and articulated this in his wellreasoned 95 theses. A situation that has some resemblance although taking place in the colonial periphery unfolded in the late 19th and early 20th centuries in the southern part of Africa. Reaction to the mainstream churches would also lead to a series of breakaway churches which have evolved into being the mainstream churches with a huge following.

It is worth noting that not all those who resisted supplanting of African heritage and culture under Christianity broke away from the mainstream churches. The first black South African ordained minister, Tiyo Soga, of the Presbyterian Church, is one prominent example of this. According to Odendaal (2012:26):

Soga has been described as someone who saw no contradiction between his Xhosa-ness and adherence to British civic nationality, though his approach to colonialism and the 'civilizing project' has been qualified as one of subversive subservience and intimate enmity ... Although framing his arguments within a missionary discourse, and not as an independent nationalist, Soga gave voice to a strong belief in the integrity and inherent value of African societies.

One of the greatest contributions and legacies of the African Christian elite in general, and the AICs in particular, is the influence they had in the formative stages of African national and even pan-African consciousness, which subsequently led to the formation of the African National Congress. This is evident in the number of prominent African clergy who went on to lead the regional, provincial and later national political formations such as the South African National Native Congress (later renamed to the African National Native Congress in 1923). John Langalibalele Dube, Walter Rubusana, Pixley ka Seme, John Tengo Jabavu, and later reverend Zachariah Mahabane and Chief Albert Luthuli, were some of the prominent cases of African nationalists who were also leaders in their churches. Some of the early articulations of this new consciousness are found in the content analysis of songs and hymns composed by the African intelligentsia in the church movement. Early western scholarship has always attributed the rise of African nationalism to the introduction of missionary education and its teachings, thus excluding the agency role of the African elite which interpreted and articulated inherent contradictions of the civilising mission of missionary movement and their direct and indirect collaboration with the colonial project.

In later years, the same movement or internal questioning of the role of the mainstream church establishment would lead to the articulation of liberation theology in Latin America and black Theology in Africa and among African Americans in the diaspora.

We have briefly outlined the nature of the AICs that broke away from and challenged the mainstream established churches in South Africa during the height of colonialism and Christianisation movement. It is clear that the leaders of this movement were change agents who, in their unique local context, tried to reform and transform the dominant churches to adjust to the African socio-political conditions. Most of the mainstream literature on church history, with a notable few, do not give due credit to the agency role of this cohort of pioneering African clergy and particularly to the early African intellectual elite, when they exclusively examine the epic clash of Reformation and Counter-Reformation Movement on a global scale. Here, the agency role of AICs gives narrative dignity to local, regional and continental reform initiatives that have often evolved without being acknowledged for their concrete verifiable impact. Little, if any, recognition is given to complex intellectual processes that led to an embrace, critical analysis and adaptation of the Christian doctrine and liturgy particularly when considering the brief period of the introduction of Christianity and the time when AICs got established within a few decades. There is a need for an in-depth analysis and interpretation of the intellectual and philosophical interventions of the early modern African intellectuals who embraced and tried to reform or adapt the form and content of what had been introduced to them. The current generation of societal and church leaders can draw some lessons about agency and change for social justice from these pathfinders in their effort to confront the challenges of our times even though the context may be different. 


\section{Acknowledgements}

\section{Competing interests}

The author declares that he has no financial or personal relationships which may have inappropriately influenced him in writing this article.

\section{References}

Cope, R.L., 1979, 'Christian missions and independent African chiefdoms in South Africa in the 19th century', Theoria: A Journal of Social and Political Theory 52:1-23.

Odendaal, A., 2012, The founders: The origins of the ANC and the struggle for democracy in South Africa, Jacana Media, Auckland Park.

Oosthuizen, G.C., 2000, 'The African independent churches in South Africa: A history in perspective', Emory International Law Review 14:909-936. 